\title{
KELAYAKAN EKONOMI USAHATANI JAGUNG DI DESA JUMO KECAMATAN KEDUNGJATI KABUPATEN GROBOGAN
}

\section{ECONOMIC FEASIBILITY OF CORN FARMING IN JUMO VILLAGE KEDUNGJATI DISTRICT GROBOGAN REGENCY}

\section{ODILO JEVADHEO KUSUMA ${ }^{1 *}$, BAYU NUSWANTARA ${ }^{2}$}

\author{
${ }^{1}$ Jurusan Agribisnis, Fakultas Pertanian dan Bisnis, UKSW Salatiga \\ ${ }^{2}$ Staff Pengajar Program Studi Agribisnis, Fakultas Pertanian dan Bisnis, UKSW Salatiga \\ *email: odilojeva@gmail.com
}

\begin{abstract}
ABSTRAK
Usahatani jagung merupakan kegiatan usaha yang menjanjikan untuk di kembangkan. Hal tersebut dikarenakan dukungan kondisi lahan yang subur, peningkatan permintaan tiap tahunnya dan kelembagaan pertanian yang ikut membantu memajukan pertanian, serta banyak petani yang menanam komoditi jagung di Kabupaten Grobogan. Produk jagung umumnya digunakan untuk pakan ternak yang berkualitas. Kondisi geografis yang strategis membuat jagung menjadi komoditi yang diusahakan oleh petani, sehingga kajian tentang pendapatan usahatani jagung dan kelayakan ekonomi menjadi penting untuk dilakukan. Penelitian ini bertujuan: 1) mengetahui gambaran pendapatan usahatani jagung di Desa Jumo, 2) menganalisis kelayakan ekonomi usahatani jagung di Desa Jumo. Penelitian ini dilakukan di Desa Jumo Kecamatan Kedungjati Kabupaten Grobogan. Sampel ditentukan secara acak pada populasi petani jagung di lokasi penelitian sejumlah 43 petani. Data primer diambil menggunakan teknik survei yakni mewawancarai petani dan informan kunci menggunakan kuesioner. Analisis ekonomi yang digunakan, yaitu: analisis pendapatan usahatani jagung, R/C ratio, dan Break Even Point (BEP). Hasil penelitian menunjukkan: 1) pendapatan usahatani jagung sebesar Rp.12.474.932,- per hektar, dan 2) R/C ratio sebesar 2,38 dan Break Even Point (BEP) harga sebesar Rp.1.364 dan Break Even Point (BEP) Volume produksi sebesar $2.800 \mathrm{~kg}$.
\end{abstract}

Kata kunci: usahatani jagung, pendapatan usahatani, $R / C$ ratio, break even point

\section{ABSTRACT}

Corn farming is a prospective business activity to be implemented. This is due to the support of fertile land conditions, an continuous increasing in demand every year and agricultural institutions that support agricultural progress, as well as many farmers who plant corn commodities such as typical in Grobogan Regency. Corn products are generally used for quality animal feed. Favorable geographical conditions make corn a commodity that is cultivated by many farmers, so it is important to do a research of farming income and economic feasibility in corn faming. The aims of this research, are: 1) to know the description of corn farming income, and 2) to analyze the economic feasibility of corn farming in Jumo village. This research was conducted in Jumo Village, Kedungjati District, Grobogan Regency. Samples were determined randomly in a population of corn farmers in the study area of 43 farmers. The primary data was taken using survey techniques, by interviewing corn farmers and key informant with a questionnaire. The economic analysis used are: analysis of corn farming income, R/C Ratio, and Break Even Point (BEP). The results of this research, are showed: 1) corn farming income in Jumo Village is IDR 12,474,932 / hectare, and 2) the $R / C$ ratio was 2.38, break even point of production volume was 2,800 kilogram, and break even point of corn price was IDR 1,364,- / kilogram.

Keywords: corn farming, income farming, $R / C$ ratio, break even point 


\section{PENDAHULUAN}

Salah satu penghasil jagung terbesar di Jawa adalah Kabupaten Grobogan, yang setiap tahunnya selalu menghasilkan jagung pipil sebagai pakan ternak golongan atas. Kabupaten Grobogan memiliki sentra produksi jagung di kecamatan: Kedungjati, Toroh, Karangrayung, Penawangan, Geyer, Pulokulon, Kradenan, Gabus, Ngaringan, Wirosari, Tawangharjo, Grobogan, Purwodadi, Brati, Klambu, Godong, Gubug, Tegowanu, Tanggungharjo (Syahrianto, 2019).

Kecamatan Kedungjati adalah penghasil jagung dengan produksi sebanyak 590.777 ton dan luas panen sebesar 105.477 ha pada tahun 2018, yang hasil panen jagung pipilnya diolah menjadi produk pakan ternak dengan kualitas unggulan (BPS, 2020). Jumlah produksi jagung yang besar di wilayah ini memberikan kontribusi bagi produksi jagung secara regional maupun nasional.

Desa Jumo merupakan salah satu desa di Kecamatan Kedungjati yang merupakan penghasil jagung dengan kulalitas yang baik. Jagung yang di tanam pada saat ini adalah jenis jagung hibrida yang tergolong berkualitas unggulan, memiliki warna biji yang orange cerah, yang di sukai para pedagang jagung pipilan dan pabrik pakan ternak (Muhadir, 1999). Jagung jenis ini sudah teruji dan terbukti tahan akan kekeringan dan setabil di berbagai kondisi penanaman, tongkolnya berisi penuh, dan dapat mencegah terjadinya penyakit busuk. Sebagian besar petani menggunakan jenis jagung hibrida dalam kegiatan usahataninya (BPS, 2020).

Dalam kegiatan budidaya jagung hal pertama yang harus dilakukan adalah pemilihan lahan, jagung memiliki sifat yang sangat toleran terhadap lingkungannya dan mampu beradaptasi dengan iklim Indonesia. Pemilihan lahan yang tepat untuk jagung adalah lahan yang kering yang berpengairan cukup, lahan yang tadah hujan, lahan terasering, lahan gambut yang telah di perbaiki, atau lahan basah bekas budidaya komoditas padi (Moelyohadi, dkk, 2012).

Penerimaan tunai usahatani (farm receipt) didefinisikan sebagai nilai uang yang diterima dari penjualan produk usahatani. Penerimaan total dari suatu usahatani jagung merupakan nilai produksi jagung per satuan luas, dikalikan dengan harga jual jagung per unit (kg) (Soekartawi, 2001).

Biaya tetap yang termasuk dalam biaya tunai adalah iuran irigasi dan tanah. Sedangkan untuk biaya variabel, yaitu biaya input produksi dan upah tenaga 
kerja. Sedangkan untuk biaya variabel, yaitu sewa lahan. Menurut Lipsey et.al (1995) biaya total (TC atau total cost) adalah biaya total untuk menghasilkan tingkat output tertentu. Biaya total terdiri dari biaya tetap total (TFC atau total fixed cost) dan biaya variabel total (TVC atau total variable cost). Biaya tetap adalah biaya yang tidak berubah meskipun output berubah. Sedangkan biaya yang berkaitan langsung dengan output, yang bertambah besar dengan meningkatnya produksi dan berkurang dengan menurunnya produksi disebut biaya variabel. total (TC) dapat dirumuskan sebagai berikut (Lipsey et.al, 1995).

Meningkatnya biaya produksi jagung karena kenaikan upah tenaga kerja dan harga input produksi jagung (benih, pupuk, pestisida), serta fluktuasi produksi jagung serta harga jual jagung yang dalami oleh petani dalam beberapa tahun terakhir ini, membuat pendapatan petani jagung terus mengalami tekanan, sehingga membuat petani jagung mengalami penurunan pendapatan dari usahatani jagung. Oleh karena itu kajian tentang aspek ekonomi, terutama dinamika biaya produksi jagung dan penerimaan usahatani jagung, serta tingkat pendapatan yang diterima petani jagung, perlu terus dilakukan.
Berdasarkan latar belakang, dapat dirumuskan permasalahan penelitian: bagaimanakah gambaran pendapatan usahatani jagung? Serta bagaimanakah kelayakan ekonomi usahatani jagung yang dilakukan oleh petani? Dari latar belakang dan permasalahan diatas, maka tujuan dari penelitian yang hendak dicapai, adalah: 1) mengetahui gambaran pendapatan usahatani jagung di Desa Jumo, 2). menganalisis kelayakan ekonomi usahatani jagung di Desa Jumo.

\section{METODE PENELITIAN}

\section{Daerah Penelitian}

Lokasi penelitian berada di Desa Jumo Kecamatan Kedungjati Kabupaten Grobogan. Pemilihan lokasi dilakukan secara sengaja (purposive). Adapun pertimbangan dari pemilihan Desa Jumo sebagai tempat penelitian karena Desa Jumo merupakan salah satu wilayah penghasil jagung hibrida dan memiliki petani jagung yang telah cukup lama melakukan usahatani jagung hibrida.

\section{Jenis dan Metode Penelitian}

Jenis penelitian ini adalah penelitian deksriptif kuantitatif, yaitu suatu metode yang tidak hanya memberikan gambaran mengenai fenomena, tetapi juga menerangkan pengaruh, menguji hipotesis, membuat prediksi serta mendapatkan 
makna dan implikasi dari suatu masalah yang ingin dipecahkan (Nazir, 2013). Penelitian ini dilakukan dengan metode suvei dengan menggunakan kuesioner yang dipandu dengan wawancara dan mendeskripsikan masalah dengan cara mengumpulkan data, menganalisis data dan selanjutnya menarik kesimpulan.

\section{Teknik Pengambilan Sampel}

Pengambilan sampel petani jagung dilakukan secara probability sampling dengan teknik simple random sampling, dengan pengambilan sampel dari anggota populasi yang dilakukan secara acak tanpa memperhatikan strata yang ada dalam populasi itu (Sugiyono, 2010). Penentuan jumlah sampel dihitung dengan menggunakan rumus Slovin, berikut ini:

$$
n=\frac{\mathrm{N}}{1+\mathrm{Ne}^{2}}
$$

$\mathrm{N}=$ ukuran populasi

$\mathrm{n}=$ ukuran sampel

$\mathrm{e}^{2}=\operatorname{error}(\%)$

Jumlah sampel (n) yang di dapat untuk penelitian ini sebesar 43 sampel petani.

\section{Analisis Penelitian}

Dalam penelitian ini, analisis ekonomi usahatani jagung dilaukan menggunakan: analisis biaya, analisis penerimaan, $R / C$ ratio dan Break Even Point (BEP).

Biaya usahatani merupakan total biaya yang meliputi biaya eksplisit dan biaya implisit yang digunakan. Besarnya biaya produksi dapat dihitung dengan rumus:

$$
\mathrm{TC}=\mathrm{TVC}+\mathrm{TFC}
$$

Keterangan :

$\mathrm{TC}=$ Biaya Total

TFC = Total Biaya Tetap

TVC = Total Biaya Variabel

Penerimaan usahatani adalah perkalian antara jumlah produksi yang dihasilkan. Besar penerimaan yang diterima dipengaruhi oleh besarnya produksi serta harga jualnya. Penerimaan dapat dihitung dengan menggunakan rumus berikut (Soekartawi, dkk. 1986) :

$$
\mathrm{TR}=\mathrm{P} \times \mathrm{Q}
$$

Keterangan :

$\mathrm{TR}=$ Penerimaan

$\mathrm{P}=$ Harga (Price)

$\mathrm{Q}=$ Jumlah Produksi (Output)

Untuk melihat penerimaan usahatani persatuan biaya yang dikeluarkan digunakan indikator Revenue Cost Ratio (R/C), dimana R/C merupakan perbandingan antara penerimaan total usaha tani dengan biaya total yang dikeluarkan selama proses produksi berlangsung. Nilai biaya dan penerimaan dapat diperoleh dari rumus (Soekartawi, 2001) :

$$
\mathrm{R} / \mathrm{C}=\frac{T R}{T C}
$$

Keterangan :

$\mathrm{R} / \mathrm{C}=$ Revenue Cost Ratio 
TR = Penerimaaan Total

$\mathrm{TC}=$ Biaya Total

Break event point adalah suatu keadaan dimana dalam suatu kegiatan usaha, tidak mendapat untung maupun rugi/impas (penerimaan=total biaya). Rumus BEP (Harga Produk dan Volume Produksi) yang digunakan sebagai berikut:

a. BEP Harga Produk:

$$
B E P=\frac{\text { Total Biaya Produksi }(\mathrm{Rp})}{\text { Total Produksi }(\mathrm{kg})}
$$

b. BEP Volume Produksi:

$$
B E P=\frac{\text { Total Biaya Produksi }(\mathrm{Rp})}{\text { Harga Produk }(\mathrm{Rp} / \mathrm{kg})}
$$

\section{HASIL DAN PEMBAHASAN}

Kabupaten Grobogan terletak di antara daerah pantai utara bagian timur dan daerah Bengawan Solo yang mempunyai tipe iklim $\mathrm{D}$ yang bersifat 6 bulan kering dan 6 bulan basah dengan suhu minimum $26{ }^{\circ} \mathrm{C}$, dan kondisi tanah di daerah Kabupaten Grobogan Kecamatan Kedungjati adalah tanah yang berbentuk perbukitan.

Karakteristik responden petani jagung Desa Jumo dapat di gambarkan melalui umur petani yang masih produktif sebagai petani karena petani dengan umur di bawah 50 lebih banyak di banding lebih dari 50, pendidikan yang di tempuh lebih besar di tamat SD, pengalaman petani yang tinggi karena sudah memiliki pengalaman bertani 30-39 tahun, dan pria lebih mendominasi pelaku usahatani jagung.

\begin{tabular}{|c|c|c|c|c|}
\hline Uraian & $\begin{array}{c}\text { Jumlah Fisik } \\
(\mathrm{kg})\end{array}$ & $\begin{array}{c}\text { Harga/ } \\
\text { Satuan (Rp) }\end{array}$ & $\begin{array}{l}\text { Nilai } \\
(\mathrm{Rp})\end{array}$ & $\begin{array}{c}\text { Persentase } \\
(\%)\end{array}$ \\
\hline \multicolumn{5}{|l|}{ Biaya Variabel } \\
\hline 1.Benih $(\mathrm{kg})$ & 15,30 & 70.000 & 1.071 .000 & 11,81 \\
\hline 2.Pupuk & & & 1.193.703 & 13,16 \\
\hline 1. Urea $(\mathrm{kg})$ & 232,10 & 1.800 & 417.780 & \\
\hline 2. Ponska (kg) & 227,40 & 2.300 & 523.020 & \\
\hline 3. Organik $(\mathrm{kg})$ & 222,38 & 833 & 185.243 & \\
\hline 4. $\quad \mathrm{SP} 36(\mathrm{~kg})$ & 33,83 & 2.000 & 67.660 & \\
\hline 3.Pestisida & & & 316.413 & 3,49 \\
\hline 1. Herbisida (botol) & 6,17 & 38.000 & 234.564 & \\
\hline 2. Insektisida (botol) & 1,96 & 35.000 & 68.726 & \\
\hline 3. Fungisida (pcs) & 0,39 & 34.000 & 13.123 & \\
\hline 4.Total Tenaga Kerja (HOK) & 146,00 & 37.548 & 5.482 .052 & 60,44 \\
\hline 5.Lain-lain (transpotasi/seleb) & & & 523.610 & 7,77 \\
\hline Total Biaya Variabel & & & 8.586.777 & 94,66 \\
\hline \multicolumn{5}{|l|}{ Biaya Tetap } \\
\hline 1.Nilai Penyusutan Alat Pertanian & & & 362.396 & 4,00 \\
\hline 2. Pajak & & & 121.765 & 1,34 \\
\hline Total Biaya Tetap & & & 484.161 & 5,34 \\
\hline Total Biaya (TC) Usahatani Jagung & & & 9.070 .938 & $\mathbf{1 0 0 , 0 0}$ \\
\hline
\end{tabular}

Tabel 1. Perhitungan Biaya Total Usahatani Jagung di Desa Jumo (1MT/ ha)

Sumber : Data Primer (2020), diolah 
Perhitungan Total Biaya Usahatani Jagung

Tabel 1. menunjukkan jika biaya variabel terdiri dari benih, pupuk, pestisida, biaya lain-lain, dan tenaga kerja yang di gunakan selama satu musim tanam jagung membutuhkan biaya sebesar Rp.8.586.777,- atau sekitar 94,66\% dari total biaya usahatani jagung. Adapun biaya yang dikeluarkan untuk biaya tetap seperti pajak dan penyusutan dengan biaya Rp.484.161,--. Total biaya yang di keluarkan petani untuk berusahatani jagung dengan luas lahan 1 hektar sebesar Rp.9.070.938,- untuk satu musim tanam (1 MT). Selanjutnya akan diuraikan perhitungan biaya benih, biaya pupuk, biaya tenaga kerja, dan biaya lain-lain (transportasi, seleb/pipil jagung).

\section{Penggunaan dan Biaya Benih}

Benih yang di gunakan pada usahatani jagung Desa Jumo adalah benih jagung hibrida jenis NK212 yang ditanam secara serempak hal ini di karenakan permintaan pasar, namun pada umumnya penggunaan benih di desa jumo tiap tahunnya selalu berbeda untuk tiap musim tanam yang terjadi selama tiga bulan. Penggunaan benih jagung oleh petani di Desa Jumo rata-rata sebesar $15,3 \mathrm{~kg}$ per hektar. Jumlah ini sesuai dengan rekomendasi dari pihak Penyuluh Pertanian Lapangan (PPL), sebesar $15 \mathrm{~kg}$ per hektar. Harga benih jagung hibrida jenis NK212 rata-rata adalah Rp.70.000,-, sehingga biaya benih per hektar yang dikeluarkan petani jagung sebesar Rp. 1.071.00,- atau sekitar $11,81 \%$ dari total biaya usahatani jagung.

\section{Penggunaan dan Biaya Pupuk}

Penggunaan pupuk petani Desa Jumo sudah mengikuti arahan yang di rekomendasikan oleh penyuluh pertanian dengan penggunaan pupuk organik, ponska, dan urea namun dalam penggunaan pupuk dapat dikatakan penggunaan yang berlebih dari yang disarankan penyuluh pertanian (PPL) pada penggunaan total pupuk yang dianjurkan penyuluh pertaian adalah sebesar $600 \mathrm{~kg}$, sedangkan rata-rata petani jagung Desa Jumo menggunakan total pupuk sebesar $715,71 \mathrm{~kg}$, (terdiri dari pupuk: urea; ponska; prill organik; SP.36), jumlah ini masih lebih tinggi dari yang direkomendasikan oleh PPL. Keadaan ini terjadi karena petani jagung merasa pupuk yang disarankan PPL masih kurang menurut keadaan di lapangan dan kemungkinan petani jagung di Desa Jumo dalam pemakaian pupuk masih boros dan tidak efisien, akibat teknik dan alat untuk menyebar pupuk yang masih manual, sehingga pemakaian tidak terukur dan tidak tepat jumlah, serta ada juga petani 
yang meniru petani jagung lainnya dengan menambahkan input pupuk yang diharapkan akan menambahkan jumlah produksi jagung (hasil panen) karena harga pupuk disubsidi pemerintah, akibatnya harga pupuk menjadi murah yang membuat petani untuk membeli dalam jumlah yang lebih banyak. Dalam penerapan pupuk organik, petani jagung di Desa Jumo menggunakan pupuk petroganik dengan jumlah fisik sebesar $222,38 \mathrm{~kg}$ dan ada beberapa petani yang memiliki ternak yang di ambil kotorannya sebagai pupuk kandang sebagai campuran petroganik.

\section{Penggunaan dan Biaya Tenaga Kerja}

Biaya untuk penggunaan tenaga kerja usahatani jagung sebagai biaya variabel menghabiskan dana sebesar Rp.5.482.052,- atau sekitar 60,44\% dari total biaya usahatani jagung, untuk tenaga kerja pria satu harinya mendapat upah sebesar Rp.40.000,- sedangkan tenaga kerja wanita sebesar Rp.35.000,-. Tenaga kerja berkerja di lahan selama sekitar 6 jam dengan waktu istirahat selama 1 jam.

\section{Penggunaan dan Biaya Pestisida}

Pestisida yang di gunakan petani jagung merupakan pestisida yang di rekomendasikan oleh penyuluh pertanian, pada penggunaan herbisida petani menggunakan neocron 80 ol, untuk insektisida yang di gunakan petani ada dua macam yaitu curacron dan emacel, sedangkan fungisida yang digunakan petani yaitu demorof.

\section{Biaya Lain-lain}

Pada penggunaan biaya lain-lain seperti: transportasi lokal, biaya seleb jagung, menghabiskan biaya sebesar Rp.523.610,- atau sekitar 7,77\% dari total biaya usahatani jagung, biaya tersebut di gunakan untuk angkut jagung dari lahan ke tempat pemipilan hingga rumah dan biaya untuk pemipilan tongkol jagung hasil panen.

Pada biaya tetap terdapat pengeluaran biaya untuk pajak PBB dan penyusutan alat pertanian dengan total sebesar Rp.484.161,- atau sekitar 5,34\% dari total biaya usahatani jagung. Pada kegiatan usahatani jagung, rata-rata petani menggunakan 4 jenis alat pertanian seperti: sprayer, cangkul, sabit dan garpu tanah, dengan jumlah masing-masing lebih dari 1 unit alat. 
Tabel 2. Perhitungan Pendapatan dan Kelayakan Ekonomi Usahatani Jagung di Desa Jumo

\begin{tabular}{lcr}
\hline \multicolumn{1}{c}{ Keterangan } & Jumlah & Nilai (Rp) \\
\hline I. Penerimaan Usahatani Jagung & & $\mathbf{2 1 . 5 4 5 . 8 7 0}$ \\
- Produksi per hektar (kg/ha) & 6.653 & \\
- Harga jual (Rp/kg) & 3.240 & \\
II. Total Biaya Usahatani Jagung & & $\mathbf{9 . 0 7 0 . 9 3 8}$ \\
III. Pendapatan Usahatani Jagung (I - II) & & $\mathbf{1 2 . 4 7 4 . 9 3 2}$ \\
IV. Kelayakan Ekonomi Usahatani Jagung & & $\mathbf{2 , 3 8}$ \\
1. R/C Ratio & & $\mathbf{2 . 8 0 0}$ \\
2. BEP Volume Produksi (kg/ha) & $\mathbf{1 . 3 6 4}$ \\
3. BEP Harga (Rp/kg) & & \\
\hline
\end{tabular}

Sumber : Data Primer (2020), diolah

\section{Pendapatan Usahatani Jagung}

Penerimaan usahatani jagung Desa Jumo sebesar Rp.21.545.870,- dengan produksi jagung 6.653,- kg per hektar dan harga jual jagung sebesar Rp.3.240,- per kilogram jagung pipil. Menurut BBPP Lembang untuk $1 \mathrm{~kg}$ benih jagung NK212 dapat menghasilkan $400 \mathrm{~kg}$ pipil jagung dengan kadar air 15\%, namun petani jagung Desa Jumo untuk $1 \mathrm{~kg}$ benih jagung dapat menghasilkan 434,71 kg pipil jagung, dalam hal ini petani jagung Desa Jumo sudah dapat dikatakan petani yang sudah menguasai bidang usahatani jagung, sehingga Desa Jumo layak untuk di katakan salah satu desa sentral jagung yang baik.

Petani jagung Desa Jumo menjual jagung pipil dengan harga Rp.3.240,-/kg untuk kadar air 15\%. Harga jual jagung akan selalu naik turun dengan jangka waktu yang tidak menentu karena harga jual jagung terbentuk bukan dari petani, namun akan lebih baik jika pemerintah membuat kebijakan tentang harga jagung karena, harga jagung tidak pernah setabil dan keuntungan pelaku usahatani jagung menjadi relatif kecil dan dengan adanya kebijakan tersebut di harapkan keuntungan petani dapat meningkat sehingga pelaku usahatani akan tetap berminat pada bidang pertanian dan dapat mengembangkan usahanya.

Dari penerimaan usahatani jagung sebesar Rp.21.545.870,- per hektar dengan total biaya usahatani jagung sebesar Rp.9.070.938,- per hektar, maka pendapatan yang diperoleh petani dari usahatani jagung di Desa Jumo adalah sebesar Rp.12.474.932,-- per hektar per musim tanam. Jumlah ini cukup baik 
mengingat pendapatan usahatani jagung lebih tinggi dari total biaya usahatani jagung yang dikeluarkan oleh petani jagung di Desa Jumo.

\section{Perhitungan R/C Ratio}

Rasio R/C atas total biaya untuk usahatani adalah sebesar 2,38 yang artinya setiap biaya yang di keluarkan sebesar satu rupiah akan mendapatkan penerimaan sebesar Rp.2,38. Dari R/C Rasio yang di dapat dari hasil wawancara dan data yang sudah di olah $R / C$ Ratio menunjukkan angka di atas 1 . Pada $R / C$ Ratio Biaya total menunjukan angka diatas 1 artinya usahatani tersebut layak untuk di jalankan, jika dibandingkan dengan $R / C$ Ratio usahatani usahatani jagung di Kecamatan Ulaweng, Kabupaten Bone Provinsi Sulawesi Selatan dari jurnal penelitian Tahir, dkk (2017) di dapat sebesar 1,72. Dalam hal ini petani jagung di Desa Jumo lebih unggul dan layak untuk dikatakan petani yang menguasai pada usahatani jagung.

\section{Perhitungan BEP Volume Produksi}

Nilai BEP volume adalah $2.800 \mathrm{~kg} / \mathrm{ha}$ dan rata-rata total produksi jagung Desa Jumo adalah sebesar 6.652,67 kg/ha yang artinya pada saat ini diatas jumlah produksi impas sebesar 2.814,84 kg/ha. Usahatani jagung Desa Jumo berada pada jumlah impas atau jumlah produksi balik modal sehingga total produksi sebesar
6.652,67 kg/ha telah melebihi jumlah impas pada kondisi total biaya usahatani jagung sebesar Rp.9.070.938,- per hektar, dengan kata lain usahatani jagung sudah memperoleh keuntungan.

\section{Perhitungan BEP Harga}

Nilai BEP harga adalah Rp.1.364,-/kg dan harga jual rata-rata yang diterima petani jagung di Desa Jumo sebesar Rp.3.240,- yang artinya pada saat harga jagung Rp.1.364,-/kg, petani jagung Desa Jumo telah memperoleh dan melampaui modalnya kembali atau diatas balik modal, sehingga harga jual rata-rata petani jagung Desa Jumo sebesar Rp.3.240,-. telah berada diatas harga impas pada kondisi total biaya usahatani jagung sebesar Rp.9.070.938,- atau dengan kata lain petani jagung di Desa Jumo berada pada posisi telah memperoleh keuntungan usahatani.

\section{KESIMPULAN dan SARAN Kesimpulan}

Berdasarkan hasil dan pembahasan diatas, dapat disimpulkan:

1. Pendapatan usahatani jagung di Desa Jumo sebesar Rp.21.545.870,- per hektar per musim tanam, dengan total biaya usahatani jagung sebesar Rp.9.070.938,- per hektar, dan pendapatan usahatani jagung sebesar Rp.12.474.932,- per hektar.

2. Kelayakan ekonomi usahatani jagung, masing-masing adalah: 
a. Nilai $R / C$ Ratio usahatani jagung sebesar 2,38. Usahatani jagung layak dan menguntungkan.

b. Nilai BEP volume adalah 2.800 $\mathrm{kg} / \mathrm{ha}$ dengan rata-rata produksi $6.653 \mathrm{~kg} / \mathrm{ha}$ dan Nilai BEP harga Rp.1.364,- dan rerata penjualan sebesar Rp.3.240,-. Nilai BEP yang didapatkan dari usahatani jagung sudah berada pada posisi yang menguntungkan.

\section{Saran}

Berdasarkan kesimpulan, maka dirumuskan saran penelitian, sebagai berikut:

1. Agar kegiatan usahatani jagung di Desa Jumo dipertahankan atau diteruskan dan volume usahanya ditingkatkan, karena usaha yang dilaksanakan dapat memberikan keuntungan. Namun penggunaan pupuk yang berlebihan dibenahi kembali, agar penggunaan pupuk menjadi lebih efisien namun petani tetap mendapatkan hasil panen yang maksimal.

2. Pemerintah diharapkan terus mendorong kegiatan usahatani jagung dan memberikan insentif kepada petani, melalui: bantuan benih, pupuk, penyuluhan dan pendampingan kepada petani, serta perbaikan infrastruktur irigasi dan jalan, karena usahatani jagung masih layak secara ekonomi dan dapat meningkatkan pendapatan petani di Desa Jumo.

\section{DAFTAR PUSTAKA}

Badan Pusat Statsistik (BPS). 2020 . Data Statistik Panen Jagung. https://bps.go.id/linkTableDinamis/view /id/868. Diakses 3 Maret 2020.

Lipsey, G.R., Peter O.S. dan Douglas D.P., (1990). Pengantar Mikro Ekonomi Jilid I. Jakarta : Erlangga

Moelyohadi, Y., M. Umar Harun, Renih Hayati, Nuni Gofar. 2012. Pemanfaatan Berbagai Jenis Pupuk Hayati pada Budidaya Tanaman Jagung(Zea mays. L) Efisien Hara di Lahan Kering Marginal. Jurnal Universitas Sriwijaya, Vol.1.No.1 Tahun 2012.

Muhadir, Fathan. 1999. Karakteristik Tanaman Jagung. Jurnal Balai Penelitian Pangan Bogor .

Nazir, Moh. 2013. Metode Penelitian. Penerbit Ghalia , Bogor.

Soekartawi, dkk. (1986). Ilmu Usahatani dan Penelitian untuk Pengembangan Petani Kecil. Jakarta: UI Press.

Soekartawi.(2001). Analisis Usahatani. UI Press. Jakarta.

Sugiyono. 2010. Metode Penelitian Pendekatan Kuantitatif, kualitatif dan $R \& D$. Bandung: CV.Alfabeta.

Tahir, Abd Gaffar, dan Suddin Andi Faisal.(2017) Analisis Pendapatan Usahatani Jagung pa Usaha tani Jagung Pada Lahan Sawah dan Tegalan di Kecamatan Ulaweng, Kabupaten Bone Sulawesi Selatan. Jurnal Balai Pengkajian Teknologi Pertanian (BPTP). 